\title{
КУЛТУРНА БАШТИНА И БИБЛИОТЕКЕ
}

\begin{abstract}
Сажетак
Улога националних библиотека у чувању културне баштине одређене земље и богатство њихових колекција указује на различите слојеве културне баштине одређене друштвене заједнице, од којих су поједини у претходним периодима били у оквиру различитих административних територија. Један од примера је некадашња СФР Југославија - шест република и две покрајине, чији је распад и прекрајање административних граница током 90-тих година XX века резултирао настанком нових тј. старих земаља. Земља је и синоним за државу, али има шире значење од речи држава.

Завичајни фондови јавних библиотека као чувари писаног културног наслеђа одређене заједнице допуна су фонду националних библиотека. Баштинске институције (музеји, архиви) на нивоу градова у Србији углавном имају своје библиотеке - специјалне, где се такође стварају колекције које су релевантне за истраживаче локалне културне баштине.
\end{abstract}

Кључне речи: културна баштина, националне библиотеке, јавне библиотеке, завичајни фондови

\section{Културно наслеђе}

Културно наслеђе чине материјално и нематеријално културно наслеђе. Материјално културно наслеђе разврстано је на покретно и непокретно. У покретно културно наслеђе спадају: музејска грађа, архивска грађа, библиотечка грађа, кинотечка грађа. У непокретно културно наслеђе спадају: споменици културе, просторне културно-историјске целине, археолошка налазишта, знаменита места. Нематеријално културно наслеђе препознато је као посебна категорија (врста наслеђа) у међународним оквирима доношењем Конвенције о нематеријалној баштини. 
За потребе Националног савета за културу септембра 2012. године, Марина Нешковић је спремила Информацију о стању у области заштите културног наслеђа. Културно наслеђе је дефинисано као „скуп свих вредности наслеђених из прошлости. Као необновљив ресурс оно представља општи интерес за Републику Србију. Његова заштита представља посебно одговорну делатност, с обзиром да су предмет рада незаменљиви оригинали изузетних вредности. Значај чувања културног наслеђа уграђен је у Устав Републике Србије: члан 89 „Свако је дужан да чува природне реткости и научно, културно и историјско наслеђе, као добра од општег интереса, у складу са законом. Посебна одговорност за очување наслеђа је на Републици Србији, аутономним покрајинама и јединицама локалне самоуправе.“ У информацији се прати и „постепена еволуција приступу заштити може се пратити и кроз развој појма културно наслеђе - посебно градитељског наслеђа - који се знатно проширио - развио се од појма појединачног споменика културе (древности из првог правног акта у Србији из 1844.) (појединачне грађевине) - до појма заштите културног предела. То је последица развоја конзерваторске науке, мисли и праксе и везано је за прихваћене међународне акте којима су дефинисани критеријум за утврђивање споменичких вредности наслеђа. Очување наслеђа данас подразумева најширу интегрисаност материјалних и нематеријалних вредности свега што нас окружује.“(1)

У актуелном тренутку теоретичари (Шошић 2014: 837) (2) који се баве дефиницијом културне баштине у својим истраживањима полазе од дефиниција које су дали Patric O'Keefe $и$ James A.R. Nefzigera, који разликују шири и ужи појам културне баштине. Појам културне баштине се у свом општем значењу односи на мноштво манифестација културе које је људски народ наследио од предака. У ужем смислу културна баштина је ограничена на малобројне објекте и нематеријалне идеје повезане тим објектима. Културна баштина има динамичан концепт. Шта се сматра културном баштином и тиме вредним заштите зависи о друштвеним приликама и тренутној културној свести у друштву, али и савременим уметничким тендецијама. Појам културне баштине се непрестано и даље развија 
и приписују му се нова значења и вредности. Термин cultural property по мишљењу аустралијских научника (Lyndel Prott и Patrick O’Keefe) ставља у први план власника тог добра, док појам cultural heritage наглашава културну вредност.

У међународној правној литератури уочен је проблем непостојања правне дефиниције појма културне баштине који се последњих деценија усталио у домену заштите културних добара. Појмови културна баштина и културно добро су резултат новијих тенденција у заштити културних добара. Док је постојала СФР Југославији Закон о заштити културних добара (1960) у члану 2. у употреби је био термин споменик културе.

Данас се културна добра не посматрају кроз призму искључиве припадности каквој националној баштини него се посматрају универзално, баштином за цело човечанство. Припадност културног добра некој држави није више нужна да би се неки артефакт сматрао вредним заштите.

Закон о културним добрима (Службени гласник РС, бр. 71/94) у члану 2. став 1. дефинише да су „културна добра ствари и творевине материјалне и духовне културе од општег интерес које уживају посебну заштиту утврђену овим законом." Члан 2. став 3. разврстава културна добра у категорије: културна добра, културна добра од великог значаја и културна добра од изузетног значаја. Карактеристике за ове категорије су детаљно описане у члану 5. овог Закона. Стара и ретка књига је одређена чланом 26. којим је и установљен критеријум - временска граница за настанак - књиге штампане до краја 1867. године.

\section{Чувари културне баштине}

Заштитом, проучавањем и очувањем културног наслеђа баве се следеће установе, чија је подела заснована на врсти и карактеру културног наслеђа: Заводи за заштиту споменика културе (непокретним културним наслеђем/добрима), музеји, архиви, библиотеке, кинотека (покретним културним наслеђем/добрима), Центар за нематеријално наслеђе (нематеријалним наслеђем). 
Различити типови библиотека - националне (у бившим југословенским републикама националне и универзитетске), универзитетске, библиотеке студијских група при факултетима, јавне, специјалне, библиотеке института, научних организација (Библиотека Српске академије наука и уметности која броји преко милион и петсто хиљада књига, библиотека поседује и збирку старе и ретке књиге, неколико легата и посебне библиотеке, картографску збирку), црквене библиотеке (Библиотека Српске патријаршије - збирка од 420 рукописних књига насталих у периоду од XIVдо XVIII века, рукописи Јована Рајића, инкунабуле и старе карте).

Библиотеке, архиви и музеји су чувари културне баштине и потенцирају улогу својих колекција у актуелном културном тренутку.

Профил данашњих колекција различитих типова библиотека представља основу за чување једног сегмента културне баштине, а уједно и надоградња колекција за сутра. Колекције периодике (посебно новине из 19. и 20. века) или „јучерашње вести“ су „сутрашње новости" за бројне истраживаче.

Завичајни фондови јавних библиотека као чувари писаног културног наслеђа одређене заједнице допуна су фонду националних библиотека. Баштинске институције (музеји, архиви) на нивоу градова у Србији углавном имају своје библиотеке - специјалне, где се такође стварају колекције које су релевантне за истраживаче локалне културне баштине. Постојање неколико примерака исте грађе даје већу вероватноћу да се иста сачува за будуће генерације.

У овим локалним фондовима посебно треба истаћи богатство некњижне грађе: разгледнице, фотографије, плакати, позивнице на различите догађаје откривају културну прошлост града. Истовремено су значајне и за проучавање живота грађана у периоду у коме су настале. Разгледнице су истовремено документ једног времена и сведочанство како је нешто изгледало.

Не треба посебно наглашавати да у фондовима различитих типова библиотека у Србији постоје легати - библиотечке целине које су допуна националној културној баштини. У овим целинама су поред књига посебно значајни рукописи, писма - коресподенција дародавца, фотографије...Тако је $\mathrm{X}$ научно-стручни скуп БИБЛИОНЕТ 
2016, одржан у Крагујевцу од 26. до 28. маја 2016. године имао за тему легате и библиотеке целине. На скупу су стручној јавности презентовани највреднији легати из српских библиотека, личности које су исте даривале библиотекама, као и садржај фондова ових целина. Поред Народне библиотеке Србије, библиотеке Матице српске Нови Сад и Универзитетска библиотека „Светозар Марковић“ у Београду у својим фондовим чува изузетно вредне библиотечке целине и легате које имају статус културног добра. (3)

Манастир Хиландар у својој библиотеци чува једну од највреднијих збирки српских рукописа. „Библиотека Свете српске царске лавре чува 1.150 рукописа и 383 хрисовуља и повеље на папиру и пергаменту, 76 примерака старе штампане књиге и 6 инкунабула, 4.518 примерака старе књиге, као и преко 40.000 књига, часописа и новина од XVII до XX века."(4)

Државни документи из периода српског средњег века - повеље владара манастирима, трговцима, писма из владарских канцеларија чувају се и ван Србије, у Историјском архиву у Котору и Државном архиву Црне Горе у Котору.

\section{Националне библиотеке}

Закон о библиотечко-информационој делатности („Службени лист РС“, бр. 52/2011) осми део члан 31. став 1 односи се на Народну библиотеку Србије и Библиотеку Матице српске и одређује да је НБС централна национална библиотека у РС, а Библиотека Матице српске је матична библиотека за територију АП Војводине.

Чланом 32. одређени су основни задаци задатке Народне библиотеке Србије са детаљним описом, а члан 33. односи се на организацију рада и управљање у Народној библиотеци Србије. Члан 34. односи се на задатке Библиотеке Мтице српске. Из таксативно набројаних послова у овом члану види се разлика између НБС и БМС која је поред што је национална библиотека задржала обележја научне библиотеке: „12) обављање рефералних послова, примање и чување докторских дисертација, магистарских радова, научноистраживачких пројеката, 
стандарда, патената, докумената и издања ФАО и УНЕСКО-а; 13) израда националног инпута за међународну базу АГРИС; 19) примање, обрада и чување поклоњених личних библиотека“.

Народна библиотека Србије је национална библиотека и депозитна библиотека за српску културну баштину. Основана давне 1832. године она је најстарија установа културе у Србији. Током XIX века била је у саставу више библиотека : Књажевско-типографска библиотека, Библиотека Попечитељства просвештенија...Временом израста у националну библиотеку. У Првом светском рату фондови су знатно оштећени, а 6. априла 1941. године приликом бомбардовања Београда Библиотека је потпуно уништена. Од 6. априла 1973. године смештена је у Карађорђевом парку у здању које је наменски пројектовао за Библиотеку архитекта Иво Куртовић (1910-1972).

Библиотека Матице српске Нови Сад основана је 1826. године, за јавност отворена 14. августа 1838. године у Текелијануму, а 1864. године пресељена је у Нови Сад. Током Првог и Другог светског рата није Библиотека радила и њене збирке су остале нетакнуте у ратним разарањима. Од 1948. године је Централна (матична) библиотека Војводине и почење да прима обавезни примерак свих штампаних ствари из Србије, а од 1965. године са територије целе ондашње Југославије. Улога и задаци Библиотеке Матице српске дефинисани су : Законом о библиотечкој делатности (1994), Законом о библиотечко-информационој делатности (2011). (5)

Библиотека Матице српске је савремена библиотека јужнословенског значаја. У фондовима чува преко четири милиона публикација на српском језику и 109 светских језика. Размењује књиге и часописе са 320 институција у свету. „Збирка рукописа броји 707 примерака, од којих су 492 ћириличне књиге. Најстарија књига је Матичин апостол из XIII века, писан на пергаменту. Библиотека Матице српске поседује и 17 инкунабула. Међу њима је и Октоих првогласник Ђурђа Црнојевића из 1493/94, прва српска инкунабула и најстарија ћириличка јужнословенска штампана књига, отиснута на Цетињу у Црној Гори. Ћирилицом штампаних књига из овог периода је 186, од којих је 157 српских. По броју српских књига XVXVII века збирка Библиотеке Матице српске је најбогатија у свету. 
Библиотека има највећу збирку српских књига 18. века (529 књига укључујући и 19 месецослова); највећу збирку српских књига 19. века (преко 5000 примерака) и најбогатију збирку српских периодичних публикација XVIII и прве половине XIX века." (6)

Посебну културно-историјску и музејску вредност имају библиотеке-целине - легати, личне библиотеке и библиотеке установа и друштава, које садрже око сто хиљада књига. Најстарија лична библиотека у фонду Матице српске је библиотека епископа Платона Атанацковића (341 дело, доспела у Библиотеку 1841.године). Овде је и легат Саве Текелије са 1984 књиге на 15 језика. Ту је и реконструисана библиотека Текелијанума са 7104 књиге на разним језицима. (7)

Национална и универзитетска библиотека Босне и Херцеговине основана је Уредбом о Народној библиотеци Федералне Босне и Херцеговине под надзором Министарства просвете („Службени лист Федеративне Босне и Херцеговине“ 31. октобар 1945.). Мисија библиотеке била је истакнута у члану 2. „да својим читаоцима омогући свестрано познавање живота и културе“, а временом је добила и универзитетску функцију. Након трагичних догађаја из 90-тих година XX века библиотека у Сарајеву која је имала улогу централне библиотеке бивше југословенске Републике Босне и Херцеговине ову функцију врши у две одвојене административне јединице подељење према националном ентитету. Правни наследник ове библиотеке је Национална и универзитетска библиотека БиХ у Сарајеву, док је у Републици српској Народна и универзитетска библиотека Републике Српске „Петар Кочић“. У октобру 1995. године, у „Службеном листу РБиХ“, бр. 37/95, објављен је Закон о библиотечкој делатности, на основу којег НУБ БиХ обавља делатност. (8)

Народна и универзитетска библиотека Републике Српске „Петар Кочић“ у Бања Луци има дугу и богату традицију која потиче из друге половине XIX века, оснивањем Српске читаонице 1868. године. Упркос бројним забранама рада Читаоница је функционисала до 1941. године. Током рата књижни фонд је страдао. Након рата 7. априла 1946. Бањалучани покрећу рад Народне библиотеке. У октобру 1956. године Народна библиотека мења име у Народна библиотека „Петар Кочић“. Након земљотреса 1969. године Библиотека 
накратко обуставља рад, а 1973. године постаје регионална матична библиотека. Оснивањем Универзитета у Бања Луци 1981. године постаје чланица Универзитета. Почиње да врши функцију универзитетске библиотеке и мења назив у Народна и универзитетска библиотека „Петар Кочић“. Од 7. децембра 1999. године библиотека обавља три функције: матичну, универзитетску и градску. (9)

Национална и универзитетска библиотека „Св. Климент Охридски“ у Скопљу формирана је 23. новембра 1944. године. Инцијални фонд биле су публикације Централне библиотеке Филозофског факултета у Скопљу. Ова библиотека била је затвореног типа, а у време од априла 1941. године до септембра 1944. године била је депозитна библиотека за бугарску књижевну продукцију. Решењем АСНОМ од 18. јануара 1945. године обезбеђено је попуњавања фонда текућом југословенском продукцијом. Библиотека је до 1991. године - до распада СФРЈ била депозитна. Фонд Библиотеке је страдао приликом поплава 1962. и земљотреса 1963. године.(10)

Данашња Национална и свеучилишна књижница у Загребу, депозитна библиотека за Републику Хрватску почетке своје делатности датира још 1607. године. Национално значење почиње стицати одредбама о обавезном примерку штампаних издања Универзитета у Пешти 1816. године, а потом доставом штампана издања из Хрватске и Славоније 1837. године. Библиотека се 1913. године сели из Ректората у зграду на Марулићевом тргу изграђену наменски за Књижницу, у стилу сецесије. Како су колекције и број публикација крајем XX века превазишли овај простор, за потребе Књижнице гради се нова зграда у коју се усељава 1995. године. Збирка старе књиге броји 9.236 јединица грађе и разврстана је у 10 група од којих су поједине: инкунабуле, глагољске књиге, ћириличне књиге, књиге из Дубровника. Збирка географских карата броји 42.000 карти, а Збирка разгледница броји 150.000 јединица. У Библиотеци се депонује и Збирка магистарских и докторских теза. Од 2007.г. формирана је Збирка стране Croatice - која обухвата хрватску књижевност у иностранству, исељеничку штампу, штампу хрватских мањина ван Хрватске. (11)

Национална и универзитетска библиотека Словеније у Љубљани почетке своје делатности повезује са Декретом Марије Терезије 
из 1774. године, а обавезни примерак публикација штампаних у провинцији Carniola прима од 1807. године. Неколико пута је мењала назив (1919.г. Државна библиотека преименује у Централна библиотека у Словенији за пријем депозита. Са оснивањем Универзитета поново мења назив у Универзитетска библиотека). Архитекта Јоже Плечник (1872-1957) урадио је пројекат за нову зграду 1930-1931.године, у коју се Библиотека пресељава 1941. године. Књижни фонд броји преко 2.800.000 јединица грађе разврстан у три колекције од који јe Slovenika главна национална колекција и 6 посебних колекција : рукописи, старе и ретке књиге, музичка колекција, мапе и географске карте, ефемера и сива литература, публикације у дијаспори и серијске публикације.(12)

У Црној Гори је 1893. године на Цетињу поводом 400-годишњице од оснивања Црнојевића штампарије основана јавна библиотека. Од 1896. године Закон о Књажеско-црногорској библиотеци даје у задатак да прикупља сва дела на свим језицима, која се баве Црном Гором, као и књижевним делима јужнословенских и словенских народа. Од 1905. године Библиотека прима по три примерка свих штампаних издања. Током Првог српског рата долази до уништења Библиотеке. Њене дужности преузима Државни музеј који обавља послове централне библиотеке за Црну Гору 1944. године. У наредном периоду Библиотека неколико пута мења назив $(1946,1964)$, а 2012. године преименована је у Националну библиотеку Црне Горе „Ђурђе Црнојевић“. (13) Фонд броји преко 800.000 јединица. Главна збирка је Montenegrina са око 45.000 јединица. (14) Збирка старе и ретке књиге броји 10.000 јединица инкунабула, постинкунабула, старе књиге - штампане ћирилицом до 1868.г. и латиницом до 1800.г. (15) Међу колекцијама су и Ликовно - графичка збирка са 74.000 плаката свих врста и 7 легата. (16)

До НАТО бомбардовања територије Србије 1999. године у Приштини је функционисала и Народна и универзитетска библиотека. Ово је била прва централна и матична библиотека на територији Косова, основана 1944. године у Призрену и прва модерно конципирана библиотека у историји Косова. У раду ове библиотеке било је прекида (1953-1963.г.). На основу Закона о оснивању Националне и универзи- 
тетске библиотеке Централна и матична библиотека добија статус националне библиотеке („Службени лист САП Косово“, 24/1970). (17) Библиотека је 1982. године смештена у зграду за коју је пројекат урадио Андрија Мутњаковић, а њен изглед је био инспирисан изгледом пчелињих саћа. Након 1999. године њено седиште је у Београду.

\section{Обавезни примерак}

Обавезни примерак представља први корак у заштити библиотечке грађе. Франсоа I је 28.12.1537. године уводи обавезан примерак као законску обавезу која треба да омогући попуњавање дворске библиотеке.

Обавезни примерак публикација у Србији се примењује од 1832. године. Током време владавине Милоша Обреновића, управник штампарије Димитрије Исаиловић, одобрио је штампање два наслова : „Басне“ Доситеја Обрадовића и „Историја славеносербског народа“" Милована Видаковића уз обавезу да се цензури достави 6 примерака, од који је један за Народну библиотеку. Током XIX века зависно од различитих актера број примерака је варирао од један до три, зависно од врсте грађе. Некада су ове уредбе садржале и казнене одредбе. Начин достављања је такође био различит -преко полиције, Управе града Београда. Уредба из 1901. године одређивала је рок за доставу публикација након штампања. Након Првог светског рата Министарски Савет је 1919. године донео одлуку да се Народној библиотеци доставља три примерка, да би овај број Законом о штампи из 1929. године био смањен на један примерак. По завршетку Другог светског рата 1944. године Председништво ACHOC-а доноси одлуку о обавезном достављању свих штампаних ствари са територије Србије Народној библиотеци у Београду. Одредба се наредне године проширала на целу Југославију, а потребни број примерака био је 15. (18)

У сету закона који се односе на библиотечко-информациону делатност током 2012. године донесен је и Закон о обавезном примерку публикација.. Закон одређује значење термина и уређује питања „обавезног примерка“. „Обавезни примерак“ је прописани број при- 
мерака публикације које на основу овог закона, издавач, односно други обвезник о свом трошку доставља надлежној депозитној библиотеци. „Локални обавезни примерак је један примерак публикације који на основу овог закона издавач, односно други обвезник о свом трошпку доставља јавној библиотеци града, односно општине у којој има седиште, односно пребивалиште, ради формирања и попуне завичајне збирке."

Достављање, прикупљање, чување и давање на коришћење обавезног примерка су послови од опшег интереса. Број примерака је регулисан чланом 7. „Народној библиотеци Србије обавезно се доставља пет примерака публикације из члана 5. став 1. тач. 1) и 2) овог закона и један примерак публикације из члана 5, став 1. тачка 3) овог закона припремљен за штампу у формату који одговара међународним стандардима универзалне доступности информација." Локални обавезни примерак доставља се на захтев надлежне јавне библиотеке града, односно општине у којој има седиште.

„Новост представља и обавеза достављања електронске копије штампане публикације у складу са чланом 8. Те копије ће моћи да се користе само на рачунарима у просторијама депозитних библиотека (Народне библиотеке Србије и Библиотеке Матице српске) и биће онемогућено њихово копирање и дистрибуција (члан 8. став 4.) Публикације треба достављати у формату PDF. Уколико издавач у предвиђеном законском року не изврши своје обавезе, Народна библиотека Србије односно Библиотека Матице српске неће израдити каталогизацију у публикација (ЦиП) и неће доделити одговарајуће међународне ознаке и универзалне стандардне бројеве (ISBN, ISSN, ISMN, DOI, ISAN и др).“

Законодавац је желео да уведе ред у ову области и да обавеже издаваче као и ауторе који су сами издавачи својих дела да ажурније достављају приерке публикације у циљу потпуности како националног фонда, тако и завичајних збирки матичних и опшштинских библиотека, које су допуна националног фонда.

Распадом СФРЈ (Социјалистичке федеративне Републике Југославије) бивше југословенске републике су законском регулати- 
вом на углавном сличне начине решиле попуњавање националног фонда текућом издавачком продукцијом.

Законом о библиотечкој делатности регулисана је библиотечка делатност у БиХ („Службени лист Републике Босне и Херцеговине“, бр. 37/95), а Национална и универзитетска библиотека Босне и Херцеговине у Сарајеву постаје централна библиотека за ову административну област. Истим Законом уређен је број обавезних примерака - 10. Такође је прецизирано да се за потребе међународне размене публикација може тражити 15 примерака. Достава новина и часописа и број примерака - један регулисана је 2003. године Изменама и допунама Закона о библиотечкој делатности („Службене новине Федерације БиХ“, бр. 28/2003).(19)

У Републици Српској обавеза прикупљања штампаних ствари регулисана је Законом о библиотечкој дјелатности („Службени гласник Републике Српске“, бр. 52/01, 39/03 и 112/08). У погледу обавезног примерка, „Законом се обавезују издавачи, односно предузећа, установе и друга физичка и правна лица која се баве издавањем штампане и на други начин умножене библиотечке грађе да Народној и универзитетској библиотеци Републике Српске доставе по 11 примерака од сваког издања, два примерка часописа и новина, три примерака уметничких репродукција."(20)

Национална и универзитетска библиотека „Климент Охридски“ Скопље је обавезу достављања обавезног примерка дефинисала као посао од јавног интереса уређен Законот за задолжителен примерак („Службен весник на Републиката Македонија“,бр. 11/94, 92/08).(21) Закон дефинише обавезни примерка да је „ово забележена информација, да је огледало, одраз и печат македонске националне културе, трајна заштита за чување националне књижевности и историју штампарства, међународна промоција и афирмација националне издавачке продукције путем укључивања у класичне и мрежне изворе информација“. Закон прецизира и број примерака - 5 од којих се један депонује као архивски, два се дају на коришћење, а преостала два се дају на чување Народној и универзитетској библиотеци „Св. Климент Охридски“ “ Битољу и Народној и универзитетској библиотеци „Гоце Делчев“ у Штипу. Временски рок предвиђен за достављање 
обавезног примерка публикација - је три месеца од објављивања публикације.

У Хрватској Закон о књижницама („Narodne novine službeni list Republike Hrvatske, br. 105/1995) чланом 37. одређује обавезу да издавачи најкасније 30 дана након завршетка штампе доставе 8 примерака. Два примерка остају Националној и свеучилишној књижници у Загребу, а по један се доставља универзитетским библиотекама у Сплиту, Ријеци, Пули, Осијеку, Мостару и општенаучним библиотекама у Дубровнику и Задру.

Локални обавезни примерак намењен попуњавању завичајне збирке законом је предвиђен у Републици Српској, Хрватској и Србији.

\section{Стара и ретка библиотечка грађа}

Скупштина Србије је 14. јула 2011. године усвојила Закон о старој и реткој библиотечкој грађ ${ }^{1}$. Новина у закону је да „уводи обавезу стручне заштите старе и ретке библиотечке грађе за све сопственике тих покретних културних добара. А не само за установе, као што је било сада. Проширен је круг библиотека које су укључене у процесе ефективне заштите старе и ретке библиотечке грађе, који је раније обухватао само Народну библиотеку Србије и Библиотеку Матице српске као депозитне библиотеке. Закон је, према наводима Министарства, унапређен и са становипште потребе за подстицањем употребе нових технологија у области заштите старе и ретке библиотечке грађе, нарочито информационих технологија и дигитализаије, што Законом о културним добрима није било предвиђено“.

Током 2013. године донета су следећа подзаконска акта која ближе одређују Закон о старој и реткој библиотечкој грађи; Правилник о ближим условима и начину коришћења старе и ретке библиотечке грађе - прописује ближе услове и начин коришћења старе и ретке библиотечке грађе у библиотекама; Правилник о мерама техничке заштите старе и ретке библиотечке грађе, Правилник

1 Закон о старој и реткој библиотечкој грађи, „Службени гласник PС“, бр. 52, (2011): 10-16. 
о садржини и начину вођења регистра категорисане старе и ретке библиотечке грађе одређује да се воде следећи регистри у електронском и штампаном облику : Централни регистар категорисане старе и ретке библиотечке грађе у РС, Регистар категорисане старе и ретке библиотечке грађе у АП Војвдини и Регистар категорисане старе и ретке библиотечке грађе у јединицама локалне самоуправе. Таксативно је наведена пратећа документација уз Регистар, као и могућност брисање категорисане грађе из Регистра. 